OAK RIDGE NATIONAL LABORATORY NUCLEAR AND CHEMICAL WASTE PROGRAMS

\title{
HAZARDOUS WASTE MINIMIZATION DURING CY 1986 AT OAK RIDGE NATIONAL LABORATORY
}

\author{
C. M. Kendrick
}

Date Published: December 1990

Prepared for the Office of Energy Research

Prepared by the Oak Ridge National Laboratory

Oak Ridge, Tennessee 37831 managed by

Martin Marietta Energy Systems, Inc. for the

U.S. DEPARTMENT OF ENERGY under Contract No. DE-AC05-84OR21400

$$
i \mid i
$$




\section{CONTENTS}

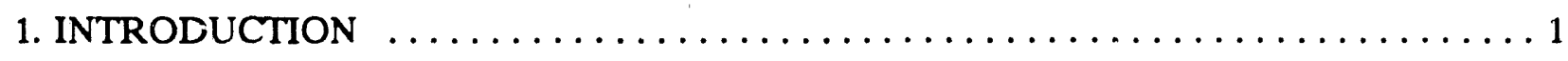

2. HAZARDOUS WASTE MINIMIZATION $\ldots \ldots \ldots \ldots \ldots \ldots \ldots \ldots \ldots \ldots \ldots \ldots$

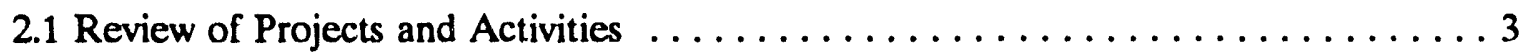

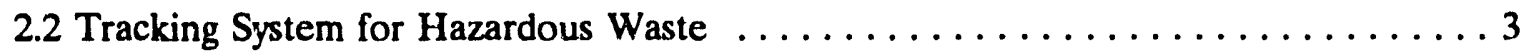

2.3 Chargeback Program $\ldots \ldots \ldots \ldots \ldots \ldots \ldots \ldots \ldots \ldots \ldots \ldots \ldots \ldots$

2.4 Procurement Practices for Hazardous Materials $\ldots \ldots \ldots \ldots \ldots \ldots \ldots \ldots \ldots$

2.5 Distribution of Surplus Chemicals $\ldots \ldots \ldots \ldots \ldots \ldots \ldots \ldots \ldots \ldots \ldots \ldots \ldots \ldots \ldots \ldots \ldots \ldots$

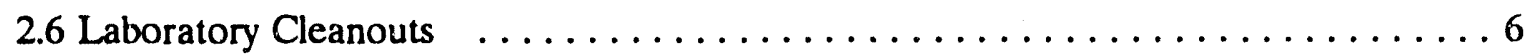

2.7 Training and Communication $\ldots \ldots \ldots \ldots \ldots \ldots \ldots \ldots \ldots \ldots \ldots \ldots \ldots \ldots \ldots \ldots \ldots \ldots \ldots$

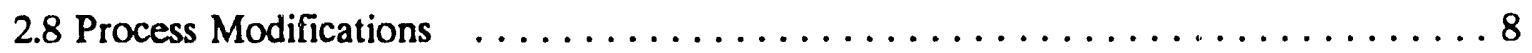

2.9 Material Recovery $\ldots \ldots \ldots \ldots \ldots \ldots \ldots \ldots \ldots \ldots \ldots \ldots \ldots \ldots$

3. MIXED WASTE MINIMIZATION $\ldots \ldots \ldots \ldots \ldots \ldots \ldots \ldots \ldots \ldots \ldots \ldots$

3.1 Liquid Waste Systems $\ldots \ldots \ldots \ldots \ldots \ldots \ldots \ldots \ldots \ldots \ldots \ldots$

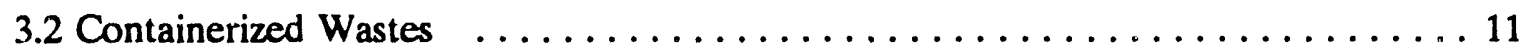

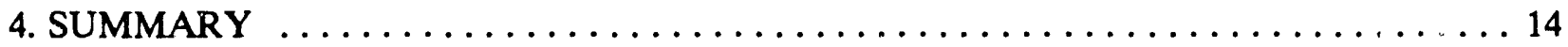

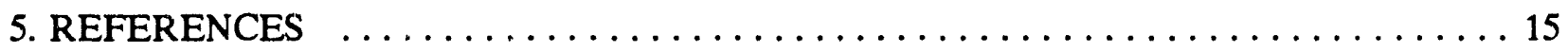




\section{INTRODUCTION}

Oak Ridge National Laboratory (ORNL) is a multipurpose research and development facility. Its primary role is the support of energy technology through applied research and engineering development and scientific research in basic and physical sciences. ORNL also is a valuable resource in the solution of problems of national importance, such as nuclear and chemical waste management. In addition, useful radioactive and stable isotopes which are unavailable from the private sector are produced at ORNL.

As a result of these activities, hazardous, radioactive, and mixed wastes are generated at ORNL. In contrast to the few, large waste streams typical of a production facility, ORNL generates numerous, small waste "streams." Illustrative of this fact is the large number, approximately 200 , of waste streams identified in the anruual hazardous waste report prepared to meet State and Environmental Protection Agency (EPA) requirements. The majority of these streams are discarded laboratory chemicals. The large number of diverse wastes complicates both their management and compliance with reporting requirements which are aimed at production facilities.

In recent years, increased effort has been devoted to the minimization of hazardous and radioactive wastes at ORNL. Policy statements supporting such efforts have been issued by both Martin Marietta Energy Systems, Inc., and ORNL management. Motivation is found in federal regulations, DOE policies and guidelines, increased costs and liabilities associated with the management of wastes, and limited disposal options and facility capacities.

ORNL's waste minimization efforts have achieved marked success. Goals for reduction of concentrated liquid low-level radioactive wastes have been established through FY 1989, and the generation rate has been reduced by approximately $57 \%$ since 1984 . Due to the diversity and predominantly nonroutine nature of ORNL's containerized wastes, goals for their reduction are more difficult to establish. Efforts to account separately for wastes generated from laboratory cleanouts, to avoid a waste minimization penalty for this goodhousekeeping practice, and establish goals for each division continue. Despite the lack of numerical goals, containerized hazardous waste generation has been reduced by approximately $19 \%$ since 1984 .

\section{HAZARDOUS WASTE MINIMIZATION}

(Waste Nos. 1-141, 152-193, 200-209)

A formal hazardous waste minimization program for ORNL was launched in mid 1985 in response to the requirements of Section 3002 of the Resource Conservation and Recovery Act (RCRA).

A Waste Minimization Committee, composed of individuals from environmental and waste management organizations, was formed. At the request of the Laboratory Director, a representative was appointed from each division to serve as the contact point for waste minimization planning and implementation. The plan for waste minimization has been modified several times and continues to be dynamic. 
During 1986, a task plan was developed. The six major tasks include:

1. planning and implementation of a Laboratory-wide chemical inventory and the subsequent distribution, treatment, storage, and/or disposal (TSD) of unneeded chemicals;

2. establishment and implementation of a distribution system for surplus chemicals to other (internal and external) organizations;

3. training and communication functions necessary to inform and motivate Laboratory personnel;

4. evaluation of current procurement and tracking systems for hazardous materials and recommendation and implementation of improvements;

5. systematic review of applicable current and proposed ORNL procedures and ongoing and proposed activities for waste volume and/or toxicity reduction potential; and

6. establishment of criteria by which to measure progress and reporting of significant achievements.

Progress toward completing these tasks has not proceeded at the desired rate due to the work load from other critical site problems judged to require priority. This is a temporary delay. The establishment of an integrated waste minimization program for all types of waste under the Environmental Restoration and Facilities Upgrade (ERFU) Program in January 1987 promises to relieve the shortage of personnel. Meanwhile, progress is being made in several areas and is summarized in Table 2.1 and described in the following sections.

Table 2.1. ORNL total" RCRA waste generation

\begin{tabular}{|c|c|}
\hline Calendar year & RCRA waste generated $(\mathrm{kg})$ \\
\hline 1984 & 100,000 \\
\hline 1985 & 105,700 \\
\hline 1986 & 81,300 \\
\hline
\end{tabular}

- Mixed waste and waste generated by ORNL activities located at the Y-12 Plant are included. 


\subsection{REVIEW OF PROJECTS AND ACTIVITIES}

ORNL has implemented, for a number of years, a program designed to provide National Environmental Policy Act (NEPA) documentation and address Department of Energy (DOE) requirements that environmental and personnel exposure during all activities be kept "as low as reasonably achievable" (ALARA). The program, which was tremendously expanded during 1985, includes three levels (Action Description Memoranda, Activities Description Memoranda, and Environmental ALARA Memoranda) of review for projects and activities. The reviews ensure that potential impacts on the environment are considered before action begins and call for measures which are considered necessary to protect human health and the environment. Wastes which will be generated are identified, and proper disposal procedures are outlined. During the review, opportunities for reduction of waste volume or toxicity by process modification. chemical substitution, or other methods are examined. The review program was expanded during 1985 to include existing, as well as new, activities. Efforts to work off the backlog of existing activities requiring review will continue for some time.

Existing waste stream documentation is being reviewed and a comprehensive Waste Stream Identification Plan is being prepared. The objective of the Plan is to identify and characterize waste streams to ensure that all wastes generated by Martin Marietta Energy Systems activities are being managed in a manner consistent with applicable DOE, federal, and state regulatory requirements. This effort will aid waste minimization efforts by supporting:

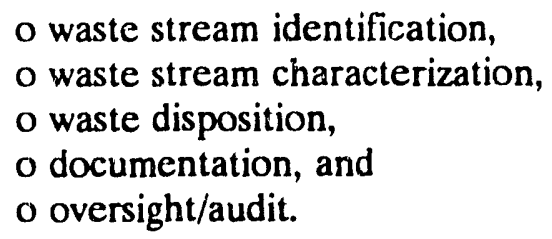

In addition to the activities described above, several divisions (Chemical Technology Division, Analytical Chemistry Division, Fuel Recycle Division, and Environmental Sciences Division) have, on their own initiative, examined their major waste-generating activities for waste reduction potential. As a result, a number of process or administrative changes have been made, and waste reductions have already been realized.

\subsection{TRACKING SYSTEM FOR HAZARDOUS WASTE}

A computerized data base is utilized for the tracking of hazardous wastes from the point of generation to ultimate disposal. Data originate from the "Request for Disposal" form completed by the generator and are logged into the data system by the Waste Operating Group. The data system has file maintenance capabilities, record query, and report generation functions which facilitate waste management. It is used primarily for record keeping, monthly billing of costs to waste generators, shipping manifest generation, disposal records, and report generation. 
The primary contribution of the waste tracking system to the waste minimization effort is its establishment of generator accountability. The data base provides records of each division's waste and enables charging the generator for associated costs.

In addition to the waste tracking system discussed above, a data system exists at ORNL to track hazardous materials from procurement to the ultimate user. This data system has not been put into operation due to difficulties in accessing the data from the procurement and stores organizations' data bases. The benefits and costs of implementing the hazardous materials tracking system will be explored as one of the tasks of the waste minimization effort.

\subsection{CHARGEBACK PROGRAM}

Cost incentives provide the most effective motivation for waste minimization. Higher waste management and disposal costs encourage researchers to examine measures to reduce waste to enhance the economic viability of their research capabilities.

While costs for hazardous waste management have been charged to the generators since 1983 , major revisions to the chargeback system were implemented in 1986. The new billing system includes cost differentials according to relative hazards of the wastes. Generators are now charged higher rates for more toxic wastes. Therefore, motivation is provided to generate not only less waste, but also less toxic waste.

Charges fall into two categories: on-site handling and off-site disposal. On-site handling costs include waste pickup, transport to storage, packaging, classification, storage, data base maintenance, auditing, training, procedures maintenance, safety and emergency response equipment, and on-site treatment, if applicable. Off-site charges are incurred if the waste is transported to a commercial disposal facility. Charges from the commercial disposal facility for each item are passed directly to the generator. The current rate schedule is shown in Table 2.2.

Beginning with the FY 1989 budget submission, which is prepared in early CY 1987, the costs for waste management will be officially included in initial task planning. Waste nıanagement costs, estimated from projections provided by the waste management organization, will be itemized by waste category. This measure will ensure that such costs, which have become substantial for many activities, are given serious consideration and will encourage planning to reduce waste. 
Table 2.2. ORNL Hazardous Waste Management Rate Schedule

\begin{tabular}{|c|c|c|c|c|}
\hline \multirow[b]{2}{*}{ Waste Category } & \multicolumn{2}{|c|}{$\begin{array}{l}\text { On-Site Charges } \\
(\mathbf{S / b})\end{array}$} & \multicolumn{2}{|l|}{$\begin{array}{r}\text { Off-Site Charges } \\
(\$ / \mathrm{b})\end{array}$} \\
\hline & $\overline{\text { Lab Pack }}$ & Bulk & Lab Pack & Bulk \\
\hline DOT Hazardous Substänce & 1.75 & 1.25 & 6.25 & 0.50 \\
\hline DOT Poison B & 2.25 & 1.25 & 5.95 & 0.50 \\
\hline Corrosive Liquid & 2.25 & 1.25 & 6.40 & 0.50 \\
\hline RCRA Toxic Substance & 2.50 & 1.50 & 6.50 & 0.50 \\
\hline PCB-Contaminated Material & 2.50 & 1.30 & 1.20 & 0.53 \\
\hline Nonhazardous Substance & 1.00 & 0.50 & 0.00 & 0.00 \\
\hline DOT Flammable/Combustible & 1.75 & 1.25 & 7.25 & 0.35 \\
\hline Explosive & 2.50 & 2.50 & 0.00 & 0.00 \\
\hline Reactive & 2.50 & 2.50 & 9.30 & 9.30 \\
\hline Photographic & 0.35 & 0.35 & 0.00 & 0.00 \\
\hline Gas Cylinder & 3.00 & 3.00 & 0.00 & 0.00 \\
\hline Recycle/Reuse & 0.35 & 0.35 & 0.00 & 0.00 \\
\hline RCRA Acute Hazardous & 2.75 & 1.50 & 6.50 & 0.50 \\
\hline Hazardous Nonspecific & 2.75 & 1.25 & 6.25 & 0.50 \\
\hline E. P. Toxic & 2.50 & 1.25 & 5.95 & 0.50 \\
\hline RCRA Ignitable & 2.50 & 1.50 & 7.25 & 0.35 \\
\hline Mercury Recycle & 1.00 & 1.00 & 0.00 & 0.00 \\
\hline Scintillation Fluid & 1.50 & 1.50 & 0.00 & 0.00 \\
\hline Unknown & 2.50 & 2.50 & 0.00 & 0.00 \\
\hline
\end{tabular}

\subsection{PROCUREMENT PRACTICES FOR HAZARDOUS MATERIALS}

Control of the procurement of hazardous materials can prevent excessive inventories, which will eventually require disposal, and require consideration of the substitution of less hazardous chemicals where possible.

One of the most important elements of procurement control is the ordering of small units. Often chemicals are less expensive to buy in bulk quantities. However, the initial cost advantage is dwarfed by disposal costs of unneeded volumes. Researchers and purchasers have been advised to purchase only the needed quantities of chemicals and to procure them in the smallest units practical.

Because of the dynamic nature of ORNL's research, periodic reevaluation of standing orders for commonly used chemicals has been requested. This will help avoid continued procurement of chemicals after the "customer" research project has been terminated. 
ORNL is a collection of over 350 individual laboratories. Often a chemical needed by one laboratory is surplus in another. Those approving purchase orders for hazardous materials for each division have been advised to check for the internal availability of chemicals before ordering. The search for available chemicals is facilitated by the periodic distribution of lists of surplus materials, which is discussed in Section 2.5.

Each division has also been advised to consider the substitution, where practical, of less hazardous cherificals in processes and experiments. Often substitution threatens the viability of the research project and cannot be implemented. However, substitution where possible r'sults in less toxic, and thus less costly, waste generation.

\subsection{DISTRIBUTION OF SURPLUS CHEMICALS}

One of the most successful endeavors of the waste minimization program at ORNL has been the distribution of surplus chemicals. Unused commercial chemicals have been estimated to constitute $90 \%$ of the waste chemicals collected at ORNL. Approximately $30 \%$ of these containers have been unopened. Since November 1985 , over $62,000 \mathrm{lb}$ of chemicals which were no longer needed by their owners have been transferred to new owners for use.

This achievement has largely been accomplished through the initiative of one individual in the Waste Operating Group, who has periodically internally circulated lists of reusable chemicals he has been asked to pick up. Response has been overwhelming; almost every item has been claimed. The original owner has benefited by avoiding the cost of disposal. The new owner has benefited by avoiding procurement costs.

Many surplus chemicals have been donated to educational institutions and to the Tennessee Department of General Services. Currently, the liabilities of distributing chemicals to outside organizations are being weighed against the benefits. However, it is likely that donations to well established institutions will continue.

\subsection{LABORATORY CIEANOUTS}

Of the approximately $160,000 \mathrm{~kg}$ of waste ORNL managed as hazardous (RCRA wastes are a fraction of this amount) cluring 1986 , well over $80,000 \mathrm{lb}$ were generated by laboratory cleanouts. One of the major tasks of the waste minimization program is the Laboratory-wide implementation of chemical inventories and cleanouts. 
This good housekeeping measure is encouraged for a number of reasons. First, clearing the work area of unneeded chemicals reduces health and safety risks. Some chemicals on laboratory shelves are as old as $\mathbf{4 0}$ years. Additional hazards are associated with aging of some chemicals, such as picric acid. Second, eliminating materials associated with expired research projects helps clear the waste generation record for current and future activities in the laboratory. One of the difficulties encountered in measuring progress in waste minimization is accounting for disposal of wastes from projects terminated in prior years. Including waste disposal costs in initial project planning, noted in Section 2.3, will help alleviate this problem in the future. Third, disposal of unneeded chemicals will be more costly in the future than today. Delaying the cleanout and disposal will only increase the costs.

\subsection{TRAINING AND COMMUNICATION}

Shortly after his or her appointment, each division's waste minimization representative was individually interviewed and trained in waste minimization concepts by a member of the Hazardous Waste Minimization Committee. A number of meetings have since been held to exchange information and ideas. Each representative is responsible for passing on the information to other employees in his or her division and initiating the implementation of waste reduction measures.

Some representatives have performed exceptionally well. The Environmental Sciences Division has recently adopted a new waste disposal procedure, which requires the preparation of a waste management plan as part of the initial planning for every new project. Elements of this plan are to include waste minimization considerations. During 1986, this Division has also completed a safety, radiation, and environmental summary form, which was produced by their own initiative, for each divisional project. This form, which is attached (Attachment 1), requests information on hazardous waste and waste minimization plans. In addition, the Division's representative, who is also the Environmental Protection Officer for the Division, has issued divisional safety and quality assurance bulletins, which stress proper waste handling. Several other division representatives have also made excellent advances for proper waste management.

An intensive campaign was launched in mid-1986 to educate generators of low-level radioactive solid waste to segregate hazardous materials from radioactive wastes. A one- to two-hour training course, which included an examination, was given to over 385 employees from every division in the Laboratory. The course included instruction in the identification of haza... us wastes, regulations for hazardous wastes, and how to segregate mixed (hazardous and radioactive) wastes from low-level waste packages. The course greatly expanded the general awareness of proper hazardous waste management practices. 
More than 80 ORNL employees participated in the RCRA Regulations Course which is taught by Government Institutes, Inc. Three two-day classes were provided for Martin Marietta Energy Systems' employees in Oak Ridge. The course included a comprehensive description of RCRA and the regulatory program; requirements for generators, transporters, TSD facilities, and permitting; and identification of hazardous wastes.

In addition, at least two ORNL employees participated in the "Hazardous and Solid Waste Minimization" course sponsored by Government Institutes, Inc., during the year.

\subsection{PROCESS MODIFICATIONS}

As a result of cost incentives and the training and communication described in Section 2.7, a number of process changes have been effected to reduce waste generation. These include recycling of waste streams into the process, measures to prevent contamination of nonhazardous materials, and process sireamiining. Examples of such modifications are described below for the Analytical Chemistry IDivision.

1. A procedural change reduced by $90 \%$ the volume of acetone-ether extractant discarded from a particular analysis.

2. The Division has requested that many of its regular customers provide smaller (e.g., $10 \mathrm{ml}$ instead of $1 \mathrm{qt}$ ) samples so that less must be discarded.

3. A new vacuum distillation system recovers about $90 \%(340 \mathrm{lb} / \mathrm{yr})$ of the Freon 113 used in the EPA-approved procedure for extracting oil and grease from aqueous specimens.

4. A change in an extraction process uses less methylene chloride and recycles the organic which is used to save approximately $1,250 \mathrm{gal} / \mathrm{yr}$.

\subsection{MATERIAL RECOVERY}

Two processes are operated at ORNL to recover frcm hazardous waste streams valuable materials for reuse or sale. Intermittently during 1986, a process was operated which recovers marketable silver-bearing sludge from photographic wastes. The process, which was developed at ORNL, achieves a volume reduction of approximately 100:1 for the hazardous waste stream.

A second recovery process, developed at ORNL in the late 1960s, is a bench-scale cleanup of used mercury and is operated by the Analytical Chemistry Division. The treatment involves two liquid/liquid extraction steps, a water wash, and vacuum drying. The mercury is then certified, bottled, and returned to the customer at a cost of about \$5/1b. Approximately 2,200 lb/yr of used mercury from ORNL are treated. 


\section{MIXED WASTE MINIMIZATION}

\subsection{LIQUID WASTE SYSTEMS (WASTE NOS. 142-145)}

Waste reduction efforts for mixed wastes at ORNL have focused on the liquid waste systems. ORNL has two liquid waste systems, the process waste (PW) system and the liquid low-level waste (LLLW) system, that are currently included on the RCRA Part A Permit Application. The two systems are interconnected. Concentrated regenerate solution from the ion exchange columns at the Process Waste Treatment Plant (PWTP) feeds into the LLLW system, and condensate and cooling water from the LLLW evaporator are returned to the PW system. Historically, approximately $30 \%$ by volume and $80 \%$ by weight of the LLLW was generated by the regeneration of the PWTP ion exchange columns.

The volume of LLLW generated has been reduced by $57 \%$ since 1984 . The average weekly generation for LLLW for 1984, 1985, and 1986 is shown in Table 3.1. This reduction is attributable to (1) a serious commitment to achieve goals established in October 1985, (2) effective implementation of an aggressive plan to attain those goals, (3) chargeback of waste management costs to generators, and (4) dry weather, which reduced the volume of contaminated groundwater which had to be treated.

Table 3.1. Average weekly LLLW generation

\begin{tabular}{|c|c|}
\hline Calendar year & LLLW generated (gal/wk) \\
\hline 1984 & 25,350 \\
\hline 1985 & 21,150 \\
\hline 1986 & 10,865 \\
\hline
\end{tabular}

The major driving force toward reduction of these wastes is the curtailment of hydrofracture for their ultimate disposal. Concentrated liquid wastes must be stored while alternative disposal technologies are studied and demonstrated. Since storage space is limited, volume reduction of currently generated waste is essential to allow time for careful selection of the alternative technology.

An aggressive LLLW volume reduction plan was developed in October 1985. The plan established goals in terms of volume available in storage tanks for LLLW concentrate. Despite several operational upsets, the actual volumes of concentrate have generally tracked the plan, as shown in Fig. 3.1. 


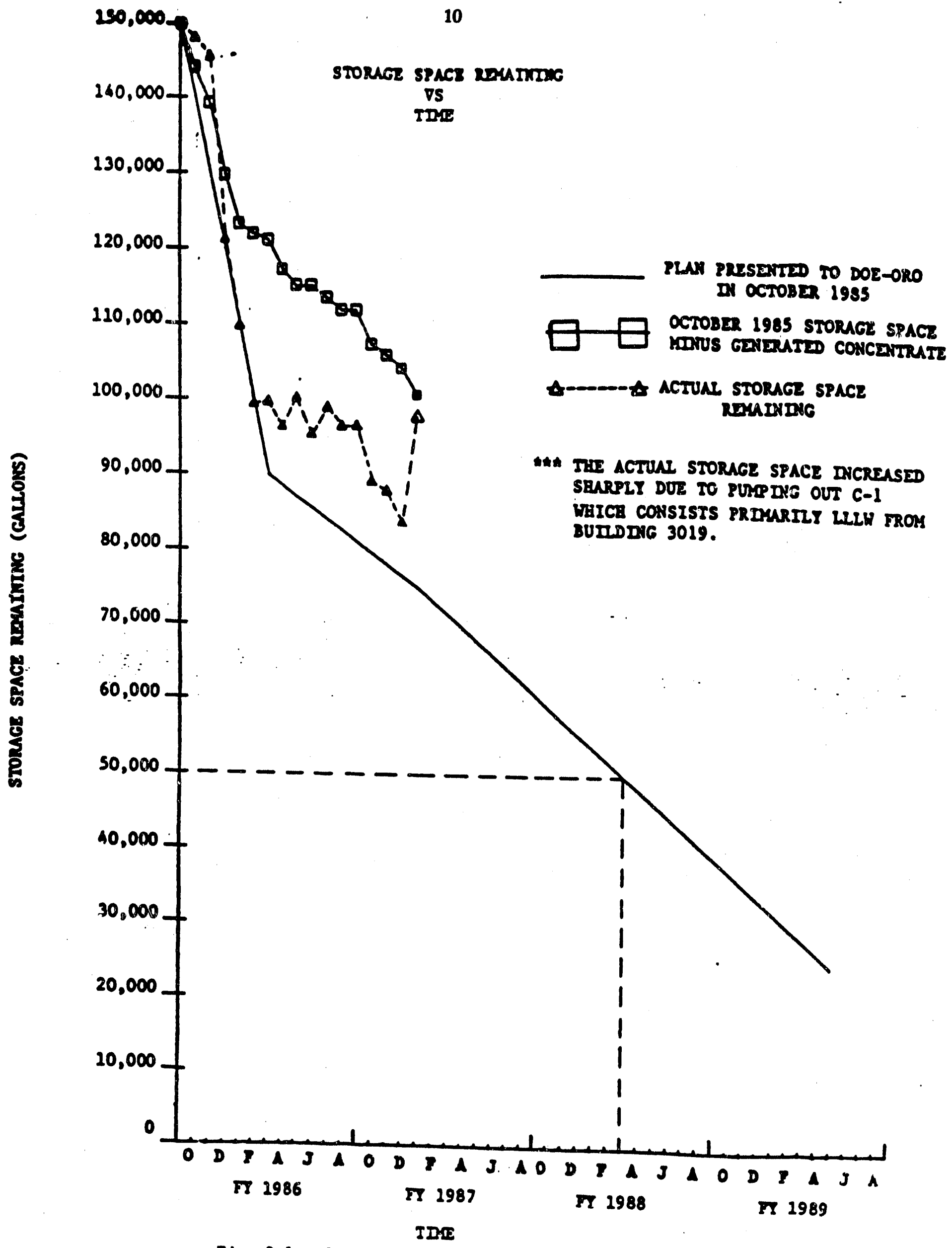

F1g. 3.1. Remainiag LLLW Storage Tank Space 
Development of the LLLW volume reduction plan involved an intensive effort to identify potential improvements in both the process waste and LLLW systems. Tables 3.2 and 3.3 list projects which were included in the October 1985 plan and others which have since been added. A variety of waste minimization techniques, including process optimization, process modification, waste segregation, and recycle, are represented among the projects.

The decrease in concentrate volume is largely due to the reinstallation of the clarifier at the PWTP, which was completed in February 1986. This unit operation precipitates out calcium and magnesium ions ("hardness") prior to treatment of the wastewater by ion exchange. These ions compete with strontium and cesium for positions on the ion-exchange medium and cause much more frequent need for column regeneration. Less frequent regeneration results in a smaller regenerate stream, a major contributor to LLLW. Before the clarifier was reinstalled, columns treated an average of $150,000 \mathrm{gal}$ of wastewater and operated for an average of $20 \mathrm{~h}$ between regenerations, compared to averages of $1,000,000$ gal and $200 \mathrm{~h}$ after reinstallation. (One column treated over $4.000,000 \mathrm{gal}$ and operated for over $800 \mathrm{~h}$ !)

An important element in the liquid waste reduction campaign is the chargeback of waste management costs to the generating programs and activities. Formerly these costs were borne by DOE Defense Program accounts. To allow time for these charges to be refiected in program budget planning, the chargeback program is being phased in gradually. During FY 1986, the Isotopes Program, which passes along its costs to customers, was charged \$3/gal for LLLW; other generators were charged \$1.50/gal. Beginning in FY 1987, all generators were charged \$4/gal. Chargeback has caused many generators to seriously examine their LLLW generating activities an $\iota^{*}$ effect reductions where practical.

\subsection{CONTAINERIZED MIXED WASTES (WASTE NOS. 146-151, 194.199)}

During 1986, approximately $14,000 \mathrm{~kg}$ of containerized mixed wastes were generated. Scintillation fluids comprised the majority of these wastes. Until 1986, mixed wastes were stored on-site awaiting eventual treatment and/or disposal. In 1986, however, two shipments, totaling 200 drums, of scintillation fluids were sent to the Quadrex incinerator located in Gainesville, Florida. The facility crushes glass vials, separates the liquid from the glass, incinerates the liquid, and decontaminates and buries the crushed glass. An incinerator at the Oak Ridge Gaseous Diffusion Plant (ORGDP), which is scheduled to begin accepting ORNL wastes in September 1987, will destroy the radicactively contaminated solvents and oils, which are now being stored. 
Table 3.2. Projects which have reduced liquid waste generation

\begin{tabular}{|c|c|c|}
\hline Project & Completion & Status \\
\hline Decoupled PWTP from LLLW & Sept. 1990 & $\begin{array}{l}88 \% \text { stream volume reduction from } \\
1984 \text { to } 1986\end{array}$ \\
\hline $\begin{array}{l}\text { Stopped pumping ground- } \\
\text { water from } 3517 \text { tank vault }\end{array}$ & Oct. 1985 & $\begin{array}{l}42 \% \text { stream volume reduction } \\
\text { from } 1984 \text { to } 1986\end{array}$ \\
\hline $\begin{array}{l}\text { Improved operation of High } \\
\text { Flux Isotope Reactor (HFIR); } \\
\text { repaired filter pit at TRU; } \\
\text { routed head tank overflow } \\
\text { back to HFIR pool }\end{array}$ & Ongoing & $\begin{array}{l}57 \% \text { stream volume reduction } \\
\text { from } 1984 \text { to } 1986\end{array}$ \\
\hline $\begin{array}{l}\text { Improved operation of the } \\
\text { ' Jak Ridge Research Reactor; } \\
\text { repaired sump }\end{array}$ & Ongoing & $\begin{array}{l}90 \% \text { stream volume reduction } \\
\text { from } 1984 \text { to } 1986\end{array}$ \\
\hline $\begin{array}{l}\text { Improved operation of } \\
\text { Isotopes Area; trained } \\
\text { operators; replaced } \\
\text { ventilation system; } \\
\text { upgraded piping }\end{array}$ & May 1986 & $\begin{array}{l}42 \% \text { stream volume reduction } \\
\text { from } 1984 \text { to } 1986\end{array}$ \\
\hline $\begin{array}{l}\text { Trained operators and } \\
\text { added instrumentation } \\
\text { at } 2026\end{array}$ & May 1986 & $100 \mathrm{gal} / \mathrm{wk}$ reduction \\
\hline $\begin{array}{l}\text { Repaired steam valve on } \\
\text { LLLW jet }\end{array}$ & Mar. 1986 & $100 \mathrm{gal} / \mathrm{wk} \mathrm{r}$ luction \\
\hline Repaired potable water leak & Feb. 1986 & $30 \mathrm{gal} / \mathrm{min}$ reduction \\
\hline $\begin{array}{l}\text { Repaired pump seal leak, } \\
3525\end{array}$ & Mar. 1986 & Minimal reduction \\
\hline $\begin{array}{l}\text { Eliminated groundwater } \\
\text { inleakage to ORR sump }\end{array}$ & Aug. 1986 & $5 \mathrm{gal} / \mathrm{min}$ reduction \\
\hline $\begin{array}{l}\text { Installed new makeup de- } \\
\text { mineralizers for reictors }\end{array}$ & Aug. 1986 & $\begin{array}{l}\text { Reduced pollutant loading on } \\
\text { watershed }\end{array}$ \\
\hline $\begin{array}{l}\text { Increase carbonate concen- } \\
\text { tration in neutralized } \\
\text { offgas solutions at TRU }\end{array}$ & Jan. 1987 & $\begin{array}{l}\text { Complete; Reduced solids } \\
\text { content }\end{array}$ \\
\hline
\end{tabular}


Table 3.3. Planned projects which will reduce liquid waste generation

\begin{tabular}{|c|c|c|}
\hline Project & Completion & Status \\
\hline $\begin{array}{l}\text { Replace in-cell transfer } \\
\text { equipment at } 2026\end{array}$ & Apr. 1987 & $\begin{array}{l}\text { Pump ordered; should eliminate } \\
\text { about } 50 \mathrm{gal} / \mathrm{wk}\end{array}$ \\
\hline $\begin{array}{l}\text { Replace decontamination } \\
\text { sprayers with higher pres- } \\
\text { sure sprayers in Isotopes } \\
\text { Area and } 3525\end{array}$ & Mar. 1987 & $\begin{array}{l}\text { Some sprayers received and in } \\
\text { use; should eliminate about } \\
100 \mathrm{gal} / \mathrm{wk}\end{array}$ \\
\hline $\begin{array}{l}\text { Segregate liquid TRU waste } \\
\text { from other LLLW }\end{array}$ & TBD & To be evaluated \\
\hline $\begin{array}{l}\text { Replace filter pit at } \\
\text { Fission Product } \\
\text { Development Laboratory }\end{array}$ & Mar. 1989 & $\begin{array}{l}\text { Delayed; would eliminate about } \\
1,000 \mathrm{gal} / \mathrm{wk}\end{array}$ \\
\hline $\begin{array}{l}\text { Solidify europium from } \\
\text { isotopes production }\end{array}$ & Nov. 1986 & On hold \\
\hline $\begin{array}{l}\text { Chemical Technology } \\
\text { Division Performance } \\
\text { Improvement Process (PIP) } \\
\text { project for volume } \\
\text { reduction }\end{array}$ & Jan. 1987 & Recommendations have been made \\
\hline $\begin{array}{l}\text { Divert steam condensate } \\
\text { ( } 3039 \text { stack) from PW to } \\
\text { storm sewer }\end{array}$ & Mar. 1987 & $\begin{array}{l}\text { Being reevaluated; would } \\
\text { eliminate about } 5 \mathrm{gal} / \mathrm{min}\end{array}$ \\
\hline $\begin{array}{l}\text { Upgrade process waste } \\
\text { piping (GPP) }\end{array}$ & Dec. 1987 & $\begin{array}{l}\text { Bid has been let; would } \\
\text { eliminate about } 30 \mathrm{gal} / \mathrm{min}\end{array}$ \\
\hline $\begin{array}{l}\text { Volume reduction to PWTP } \\
\text { (GPP) }\end{array}$ & Sept. 1988 & $\begin{array}{l}\text { Planned; would eliminate about } \\
18 \mathrm{gal} / \mathrm{min}\end{array}$ \\
\hline
\end{tabular}


The major waste minimization measure applied to these streams is segregation of radioactive from hazardous materials. The combination of chemical and radioactive hazards creates a waste which is much more difficult and costly to manage. The training program described in Section 2.7 taught waste generators to identify and isolate hazardous materials from radioactive wastes when possible.

Health physics and waste management personnel continue to examine the practice of pouring together the contents of small containers, such as scintillation vials, as a measure to reduce waste volume. The containers would then be decontaminated and disposed as nonhazardous waste. For some types of mixed waste, this practice is already being implemented.

The substitution of nonhazardous scintillation fluids for those currently utilized by ORNL researchers is being studied by Oak Ridge Associated Universities (ORAU). If the study finds and researchers can be convinced that the new fluids will not degrade the quality of their data, the substitution will result in a waste stream which the EPA has approved for discharge into municipal sewer systems.

Chargeback of waste management costs, described in Section 2.3, is also implemented for containerized mixed wastes.

\section{SUMMARY}

The reduction of hazardous waste generation is an economically logical response to the rising costs and liabilities of waste management and disposal. Human health and the environment are best protected from hazardous wastes by prevention of their generation from the start. At ORNL, efforts to minimize hazardous waste have been mandated by federal regulations and DOE, Martin Marietta Energy Systems, Inc., and internal policies. Real progress has been achieved, particularly in the reduction of liquid radioactive waste and the distribution of surplus chemicals. As researchers become increasingly aware of the advantages of improving the efficiency of their procedures and as divisions launch systematic evaluations of activities with reduction potential, further reductions will be achieved. 


\section{REFERENCES}

1. Letter from Herman Postma to Joseph A. Lenhard, "Award Fee Criteria for Waste Management Activities," April 30, 1986

2. Letter from J. LaGrone to K. Jarmolow, "Waste Handling, Martin Marietta Energy Systems, Inc., July 15, 1986

3. Letter from B. J. Davis to Distribution, "Waste Streams Identification and Evaluations - Oak Ridge Operations Facilities," July 29, 1986

4. Letter from M. E. Mitchell to R. G. Donnelly, et. al., "Waste Streams Identification and Evaluations - Oak Ridge Operations Facilities," October 23, 1986

5. Oral presentation by F. R. Mynatt to ORNL Executive Committee, prepared by J. B. Berry, "Progress Report on Waste Reduction and Cost Recovery Activities," November 5, 1986

6. Letter from Herman Postma to Joseph A. Lenhard, "RCRA Waste Minimization Progress During CY 1985," November 7, 1986

7. Letter from Thomas H. Row to W. D. Adams, "Hazardous Waste Minimization Program," December 9, 1986

8. J. B. Berry, L. G. Hill, P. E. Hollenbeck, L. E. McNeese, T. E. Myrick, R. E. Pudelek, P. S. Rohwer, J. H. Smith, H. R. Yook, E. L. Youngblood, Environmental Restoration and Facilities Upgrade Preliminary ORNL Long-Range Environmental Management Plan and Budget Document Draft Preliminary, ORNL/6345, December 1986. 
ENIRONISTAL SCIENCES DIVISION

SAFETY, RADIATION, AND ENIIRONIENT SUMHARY

fOR NEU OR REVISED RESEARCH

"SRE Summary" Form *

Date , 19

1. Responsible Staff Member:

Phone:

2. Title of Research:

3. Location of work: Building Room Field site

4. Starting Date: , 19 Estimated duration:

5. Have written research procedures been prepared? YES or NO. If YES. attach a copy. If NO give a brief description of the research.

b. List hazardous chemicals (toxic, teratogens, carcinogens, etc.) and/or radioisotopes to be used. Include quantity, concentration, activity, and chemical form for each chemical/radioisotope as acalicable.

7. List personnel who will be involved in the use of the above chemicals and/or radioisotopes:

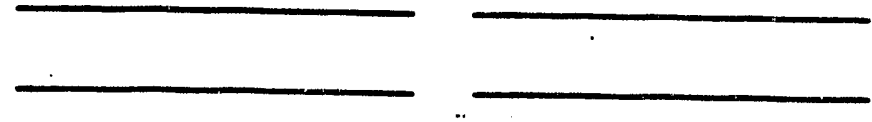

B. Have you consulted outside your group regarding the safety of this research? VES or Mo. If VES, who? 
9. Will hazardous waste be generated? YES or NO. If YES describe the waste, estimate the amount, describe disposal methods, and describe the waste minimization procedures you plan to use.

10. Do research personnel require additional training to be proficient in recognizing and dealing with the hazards associated with this work? YES or NO. If YES, describe training needs.

11. Is safety equipment needed to perform this research? YES or NO. If YES, then describe what is needed.

12. Are there health hazards associated with this research work? - YES or NO. If YES, give a brief description of the procedures/equipment that will be used to minimize the health hazards.

13. If radionuclides are used in this research do plans include labeling, zoning, and containment provisions in accordance with Procedures 2.3, 2.7, and Appendix A-7 in the Health Physics Procedure Manual? VES or NO.

14. Other comments: 
15. Does the work involve the following health or safety hazards?

\begin{tabular}{|l|l|l|l|}
\hline YES & NO & Hazard & If YES Describe \\
\hline & & Flammable materials & \\
\hline & & Vacuum/pressure equipment & \\
\hline & & Moving neavy items & \\
\hline & & Corrosives & \\
\hline & Explosive materials & \\
\hline & Electrical shock & \\
\hline & & & \\
\hline
\end{tabular}

Apronals

Principal Investigator:

Section Head:

ESD ISO/RCO:

Heal th Phrsics:

Industrial Hygiene:
Safety

Summary?

Date:

YES NO

Dete:

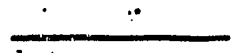

YES NO

Date:

VES NO

Date:

YES NO

Date:

YES NO

Detailed Safety Summary Rrquired: VES no 


\section{SRE SUMMAPY FORM INSTRLCTIONS}

The Principal Investigator is responsible for initiating and updating this form. This form is required for all new research and for charge to existing research tifat increases or adds hazards. Amenuments may be used to update existing forms. This is a living document, please keep it current. Please write legibly or type. Continuation sheets may be added.

1. The Division Safety Officer (DSO) will assign the form number.

2. Fill in the date the form is prepared.

3. Fill in your name, phone number, and the name of the research project. Indicate where the work will be performed.

4. Give the starting date for the research and estimate how long the work will last (number of weeks, months, years, etc.).

5. If a research description has been prepared or if research procedures have been prepared attach a copy to this form. If no existing deseriptions are applicable then briefly describe the research here. Give sufficient detail for safety evaluation of the research. If additional roon is required please add a continuation sheet and reference the question number.

6. List all hazardous and radioactive chemicals to be used in the research. Give details about the quantities to be used, concentrations, activities of radioisotopes, and the chemical form of the materials.

7. Names of the people who will work with the hazardous materials listed in $\# 6$. Keep the names on this list updated.

8. List the names of those who have advised or consulted you on the safety aspects of this research.

9. Estimate the imount of hazardous waste to be generated (weight or volume). Deseribe the waste and how it will be disposed of. Describe the procedures that will be used to minimize the amount of waste generated?

10. Describe the additional training research personnel will require to safely perform the proposed research.

11. Additional safety equipment needed for this work should be listed or described here.

12. If workers will be exposed to health hazards describe what will be done to minimize the hazards.

13. Check the Health Physics Procedure Manual for these requirenients.

14. Other: comments about the research project pertaining to the intent of this form can be added here.

15. This is a list of additional health or safety hazards that may apply to your research. Add any applicable hazards that are not listed and briefly describe then.

16. APPROVALS: Signatures of the Principal Investigator and Section Head are required.before routing to the ESD DSO/RCO. The DSO/RCO may route the form to Health Physics and Industrial Hygiene as required. Each signatory should indicate if they feel a Safety Summary should be required by circling the YES or NO after the date. The DSO/RCO will decide if a detailed Safety Summary will be required based on the recomandations of the signatories. A copy of the signed forminill be returned to the originator as soon as possible. 

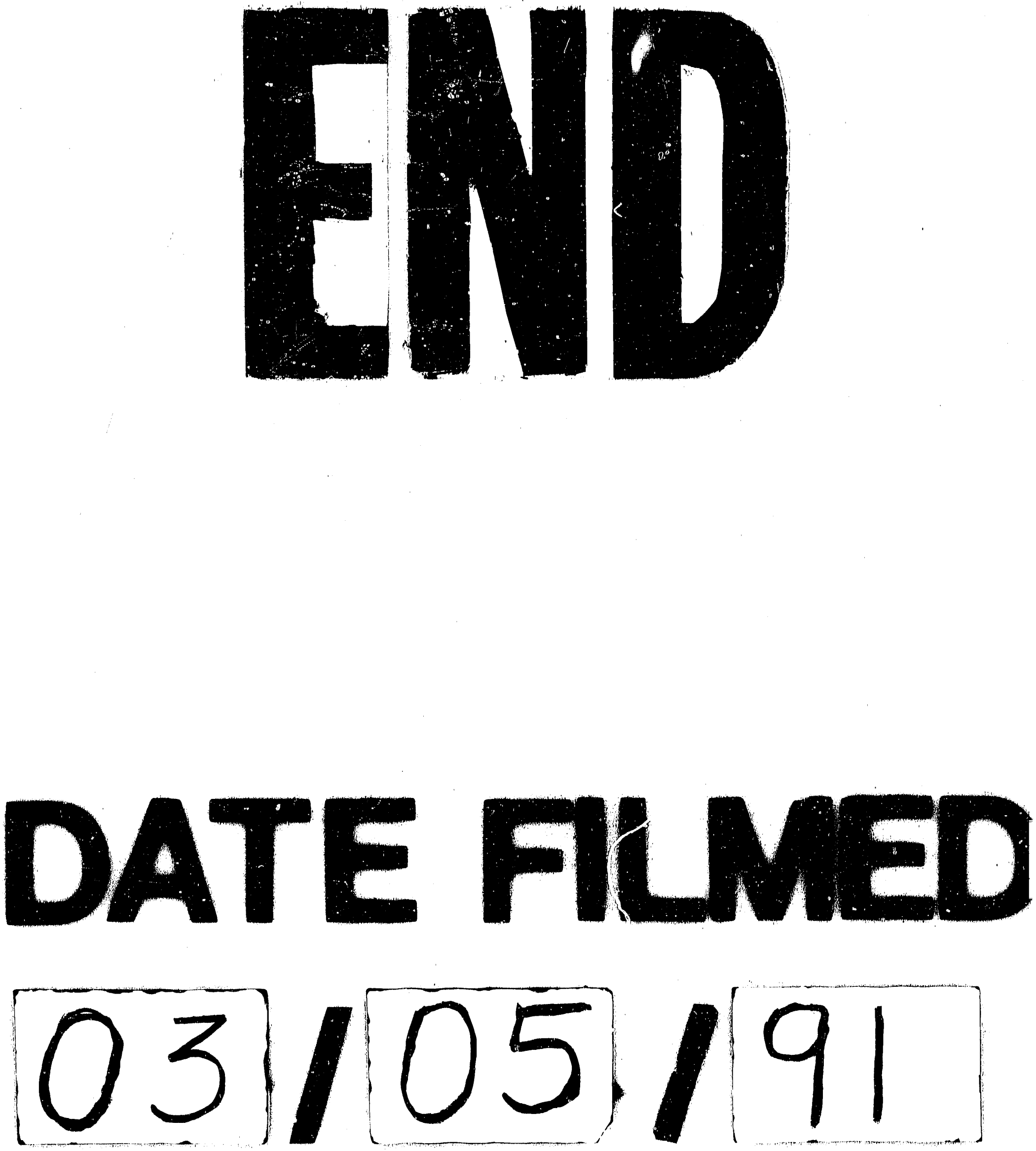
